\title{
Banque Fédérale
}

(SOCIETE ANONYME)

Bâle . Berne . La Chaux-de-Fonds St-Gall . Vevey . Zurich . Lausanne

MOLA A D

Téléph. 49200

\section{GENE VE}

Traite toutes opérations de Banque aux meilleures conditions

Conseils sur placements financiers et toutes les questions concernant le trafic international des paiements 


\title{
Sommaire du Bulletin
}

\author{
T. LXXIV, No 489 \\ MAI I 943
}

Comité international. - Le Comité international et la guerre, 413. - Communiqués du Comité international : Visite au Comité international du Ministre de Bulgarie, à Berne, 413. - Rapatriement de prisonniers de guerre, blessés et malades et de membres du personnel sanitaire, 413. - Demandes d'enquête présentées au Comité international, 414. - Liste des principaux articles consacrés au Comité international et à l'Agence centrale des prisonniers de guerre, 415.

Ligue. - Bulletin de la Ligue, 416. - Publication, 416.

Bulgarie. - Les secours aux victimes des calamités publiques, 417.

Danemark. - Activité de la Croix-Rouge danoise pendant l'année 1942, 418.

Finlande. - La Croix-Rouge finlandaise et les invalides de guerre, 419.

Grande-Bretagne. - Colis pour prisonniers de guerre, 420.

Suisse. - Euvre de secours en faveur des enfants grees (hors-texte), 421.

La Revue internationale de la Croix-Rouge, Bulletin international des Sociétés de la Croix-Rouge, parait à la fin de chaque mois.

Rédaction: M. Henri Reverdin, M. Louis Demolis, membres du Secrétariat du Comité international de la Croix-Rouge

Administration : M. Louis Demolis

Prix, franco, un an : Fr. 20. -

Le numéro: $\mathrm{Fr}$. 2.-

Abonnements, vente au numéro, publicité, au Siège du Comité international

HôTEL DE LA MÉTROPOLE - GENÈVE

Téléphone : $55200 \quad-\quad$ Compte de chèques: I. 1767 